\title{
DMPA- Induced Changes in Estrogen and Progesterone Receptors of Ampulla of Rat-oviducts: An Immunohistochemical Study
}

\author{
Raafat Hegazy ${ }^{1}$, Abdelmonem Hegazy ${ }^{2, *}$ \\ ${ }^{1}$ Department of Pathology, Faculty of Medicine, Zagazig University, Egypt \\ ${ }^{2}$ Department of Anatomy and Embryology, Faculty of Medicine, Zagazig University, Egypt
}

Copyright (C) 2015 Horizon Research Publishing All rights reserved.

\begin{abstract}
To evaluate the changes in estrogen (ER) and progesterone (PR) receptors in oviducts, their immunohistochemical expression was investigated using albino rats in estrous cycle and after administration of depot-medroxy progesterone acetate (DMPA). Materials and methods: Twenty rats underwent this study were classified into groups, five rats were sacrificed in the morning of first day (follicular stage); another five rats were sacrificed in the morning of the second day (luteal stage); and ten rats were injected with $12.5 \mathrm{mg}$ subcutaneous DMPA in the first day of cycle, then sacrificed in the next day to show changes in ER and PR. Paraffin-embedded blocks were prepared from the ampullae of oviducts. Then, immunohistochemical staining was performed for each block. Results: ER immunoreactivity mainly nuclear was expressed in the glands, pseudoglands, stromal cells and vascular endothelia in the follicular phase; becoming cytoplasmic in the luteal phase, expressed mainly in the cytoplasm of luminal epithelial cells, and nearly the same picture after DMPA injection. PR immunoreactivity mainly nuclear was expressed in the glands, pseudoglands and stromal cells in the follicular phase; becoming moderately expressed in the luteal phase, but reached a maximum after DMPA injection. Conclusions: DMPA injection caused increased expression of PR but not affecting ER expression.
\end{abstract}

Keywords Oviduct, Estrogen Receptors, Progesterone Receptors, Immunohistochemical Expression, DMPA

\section{Background}

The oviduct (synonyms Fallopian tube, salpinx, uterine tube) firstly described by Gabriel Fallopius in 1561, was considered a simple connection between the ovary and the uterus for a long time. Today, it is regarded as one of the most dynamic reproductive organs, whose functional aspects are not yet fully understood [1]. It plays a pivotal functional role in reproduction, as it is the site of fertilization [2]. Moreover, it provides an environment that enhances and supports fertilization and early embryonic development, along the travel of embryo toward the uterine cavity $[3,4]$. In spite of having little knowledge about the mechanism of the embryo transport within the tube, both tubal peristalsis and cilial activity are thought to be important for successful embryo transport[5]. These reproductive events are regulated mainly by the plasma and/or peritoneal fluid ovarian steroid hormones, estrogen and progesterone, which influence the ciliary activity, the composition of tubal fluid and tubal peristalsis [5-7]. The influence of ovarian steroids is likely mediated through their corresponding receptors which vary in concentration according to menstrual cycle [8]. Despite extensive research on expression of sex steroid hormone receptors in female reproductive tissues of humans and laboratory rodents, expression, localization and function of these receptors in the oviduct remain unclear [9]. At the same time, the precise effect of hormonal contraceptives such as DMPA "a long-acting progestin" on the Fallopian tubes remains unclear. Regarding this aspect, the short estrous cycle in the rat, lasting four to five days, makes it an ideal animal for such research [10].

Aim of the study

To highlight the immunohistochemical localization, and distribution of estrogen and progesterone receptors in the normal oviducts in rats in follicular and luteal phases, and after administration of exogenous progesterone "DMPA".

\section{Materials and Methods}

\subsection{Animals and Experimental Design}

Twenty sexually mature female albino rats, 6-8 weeks old and weighting 230-380 gm were housed in stainless-steel cages. The animals were housed cage at the animal house of Zagazig Faculty of Medicine under standard conditions of 
temperature (22 to $\left.24^{\circ} \mathrm{C}\right)$, luminosity $(12: 12 \mathrm{~h}$ light/dark cycles) and humidity (60\%). Food and water were available ad libitum. Experimental procedures were approved by the Scientific and medical research center 'ZSMRC' of Zagazig university. The animals were divided into two groups; each one was formed of ten rats. The animals of the two groups were separated in individual cages under good healthy conditions. Daily vaginal smears were done to determine the phase of estrous cycle for each animal [11]. Five animals from the first group were anesthetized with an overdose of ether, and sacrificed in the morning of the first day of cycle (follicular phase); the other five animals of this group were sacrificed in the morning of the second day (luteal phase). The second female group (ten animals) was injected in the first day of cycle, subcutaneously with $12.5 \mathrm{mg}$ DMPA "Depo-Provera" [12]. One day after treatment, the treated animals were sacrificed. The ventral abdominal wall of each animal was opened through a longitudinal section.

\subsection{Tissue Sampling}

Oviducts were identified and removed. Both ampullae from the right and left oviducts of each animal were dissected. Immediately after excision, the ampulla was carefully cleaned from the surrounding tissues, and then cut into small pieces of equal length. Tissue specimens were fixed in $10 \%$ neutral buffered formalin for 12 hours before dehydration in ascending grades of alcohol then paraffin embedding.

\subsection{Immunohistochemistry}

According to Santiago et al., [13] with modifications: Serial sections from the paraffin embedded blocks were cut at $5 \mu \mathrm{m}$ thickness and mounted on slides coated with poly-l-lysine (Sigma). Slides were deparaffinized, rehydrated through graded concentrations of alcohol to distilled water, transferred to sodium citrate buffer ( $\mathrm{pH}$ 6.0), and heated two times for $10 \mathrm{~min}$ in a microwave oven, set at $800 \mathrm{~W}$. Slides were cooled between microwave irradiations for $5 \mathrm{~min}$. After this procedure, slides were washed twice with $10 \mathrm{mM}$ PBS, pH 7.4, and incubated successively in: $3 \%$ hydrogen peroxide in PBS for $30 \mathrm{~min}$ (at room temperature), $1 \%$ normal goat serum plus $1 \%$ hydrogen peroxide in PBS for $30 \mathrm{~min}$; $0.5 \%$ Triton X-100 in PBS for $30 \mathrm{~min}$; PR, or ER mouse monoclonal antibody, ready to use (DAKO, USA) for 12 hours at $4^{\circ} \mathrm{C}$ in a humid chamber. Slides were incubated with a biotinylated secondary antibody for 2 hours at room temperature and later with conjugated streptavidin-peroxidase for 1 hour. Sections were washed twice with PBS among incubations. Peroxidase activity was evidenced by using 3, 3_-diaminobenzidine chromogen solution in the presence of hydrogen peroxide for $10 \mathrm{~min}$. After washing, sections were counterstained with Mayer's hematoxylin, then sections were dehydrated and a cover slip was applied with mounting medium (DPX). Negative
Control sections were incubated with pre-immune goat serum (1:2000) in place of the primary antibody. Positive control sections were taken from endometrial tissue of the same rat.

\subsection{Morphometric Analysis}

Scoring of nuclear or cytoplasmic immunoreactivity of ER or PR in cells was done by the two authors (RH, AH) blindly and independently through manually counting the number of stained cells. Five hundred cells in the most strongly positive section were counted by light microscopy (400_magnification). Overexpression or positivity was defined as more than $20 \%$ of the examined cells displaying staining.

\subsection{Statistical Analysis}

For statistical analysis, the categories were divided into these two categories; positive and negative, or strong and weak reaction. Data were represented as numbers and percentages. The differences were compared for statistical significance by chi-square test. Difference was considered significant at $P<0.05$. The statistical analysis was performed using (SPSS 16.0 for Windows; SPSS Inc. Chicago, Illinois, USA).

\section{Results}

In the follicular phase, ER was immunoreactive (i.e. more than $20 \%$ of the examined cells). There was strongly nuclear positivity in the glands, pseudoglands, the luminal epithelium and the stromal cells in four rats $(80 \%)$ associated with positivity occurred in the luminal epithelial cells in only one rat $(20 \%)(P=0.001)$. Nuclear immunoreaction was strong in the endothelial cells of vasculature of three rats $(60 \%)$ associated with strong nuclear reactivity in the stromal and muscle cells in 4 rats $(80 \%)(P=0.001)$, (Table 1 , Figures 1-6).

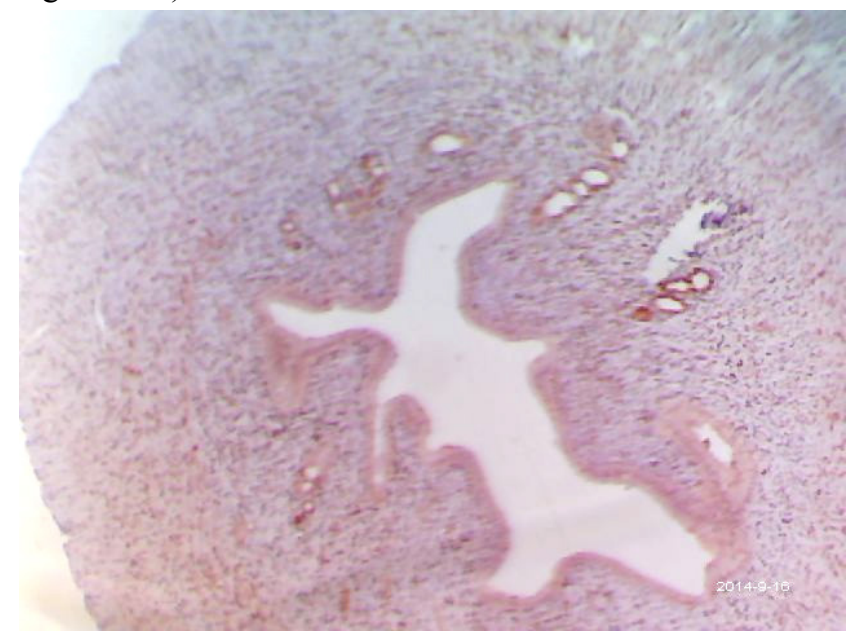

Figure 1. ER positive reaction in the glands, pseudoglands, and negative in luminal epithelial cells (nuclear staining), rat oviduct, follicular phase, $\mathrm{x}$ 100 . 
Table 1. Immunohistochemical expression of ER and PR in the tissue elements of ampulla of oviduct in follicular and luteal phases and after DMPA injection

\begin{tabular}{|c|c|c|c|c|c|c|c|c|c|c|}
\hline \multirow{2}{*}{ Phase } & \multirow{2}{*}{$\begin{array}{l}\text { Rat } \\
\text { No. }\end{array}$} & \multirow{2}{*}{ Tissue elements } & \multicolumn{4}{|c|}{ ER } & \multicolumn{4}{|c|}{ PR } \\
\hline & & & $+\mathrm{ve}$ & -ve & $\mathrm{N}$, or $\mathrm{C}$ & $P$ value & $+\mathrm{ve}$ & -ve & $\mathrm{N}$, or $\mathrm{C}$ & $P$ value \\
\hline \multirow{4}{*}{ Follicular } & \multirow{4}{*}{5} & Luminal epithelial cells & $1(20 \%)$ & $4(80 \%)$ & \multirow{2}{*}{$\mathrm{N} \mathrm{N}$} & \multirow{2}{*}{0.001} & \multirow{2}{*}{$\begin{array}{l}1(20 \%) \\
4(80 \%)\end{array}$} & \multirow{2}{*}{$\begin{array}{l}\mathbf{4}(80 \%) \\
1(20 \%)\end{array}$} & \multirow{2}{*}{$\mathrm{N} \mathrm{N}$} & \multirow{2}{*}{0.001} \\
\hline & & Glands, pseudoglands & $4(80 \%)$ & $1(20 \%)$ & & & & & & \\
\hline & & Stromal cells, muscle cells & $4(80 \%)$ & $1(20 \%)$ & NI & $000 ?$ & $5(100 \%)$ & 0 & $\mathrm{~N}$ & 001 \\
\hline & & Vascular endothelial cells & $3(60 \%)$ & $2(40 \%)$ & IV IN & 0.002 & 0 & $5(100 \%)$ & - & 0.001 \\
\hline \multirow{4}{*}{ Luteal } & \multirow{4}{*}{5} & Luminal epithelial cells & \multirow{2}{*}{$\begin{array}{l}4(80 \%) \\
1(20 \%)\end{array}$} & $1(20 \%)$ & \multirow{2}{*}{$\mathrm{C} \mathrm{C}$} & \multirow{2}{*}{0.001} & \multirow{2}{*}{$\begin{array}{l}3(60 \%) \\
3(60 \%)\end{array}$} & \multirow{2}{*}{$\begin{array}{l}2(40 \%) \\
2(40 \%)\end{array}$} & \multirow{2}{*}{$\mathrm{N} \mathrm{N}$} & \multirow{2}{*}{$\begin{array}{l}1.000 \\
(\mathrm{NS})\end{array}$} \\
\hline & & Glands, pseudoglands & & $4(80 \%)$ & & & & & & \\
\hline & & Stromal cells, muscle cells & \multirow{2}{*}{$\begin{array}{c}0 \\
1(20 \%)\end{array}$} & $5(100 \%)$ & \multirow{2}{*}{$-\mathrm{N}$} & \multirow{2}{*}{0.001} & \multirow{2}{*}{$\begin{array}{c}3(60 \%) \\
0\end{array}$} & \multirow{2}{*}{$\begin{array}{c}2(40 \%) \\
5(100 \%)\end{array}$} & \multirow{2}{*}{$\begin{array}{l}N \\
-\end{array}$} & \multirow{2}{*}{0.001} \\
\hline & & Vascular endothelial cells & & $4(80 \%)$ & & & & & & \\
\hline \multirow{4}{*}{$\begin{array}{c}\text { After DMPA } \\
\text { injection }\end{array}$} & \multirow{4}{*}{10} & Luminal epithelial cells & $8(80 \%)$ & $2(20 \%)$ & \multirow{2}{*}{$\mathrm{C} \mathrm{C}$} & \multirow{2}{*}{0.001} & \multirow{2}{*}{$\begin{array}{l}8(80 \%) \\
8(80 \%)\end{array}$} & \multirow{2}{*}{$\begin{array}{l}2(20 \%) \\
2(20 \%)\end{array}$} & \multirow{2}{*}{$\mathrm{N} \mathrm{N}$} & \multirow{2}{*}{$\begin{array}{l}1.000 \\
(\mathrm{NS})\end{array}$} \\
\hline & & Glands, pseudoglands & $2(20 \%)$ & $8(80 \%)$ & & & & & & \\
\hline & & Stromal cells, muscle cells & 0 & $10(100 \%)$ & $N$ & $0 \Omega r$ & $8(80 \%)$ & $2(20 \%)$ & $\mathrm{N}$ & 1 \\
\hline & & Vascular endothelial cells & $2(20 \%)$ & $8(80 \%)$ & -14 & 0.001 & 0 & $10(100 \%)$ & - & $0 . .001$ \\
\hline
\end{tabular}

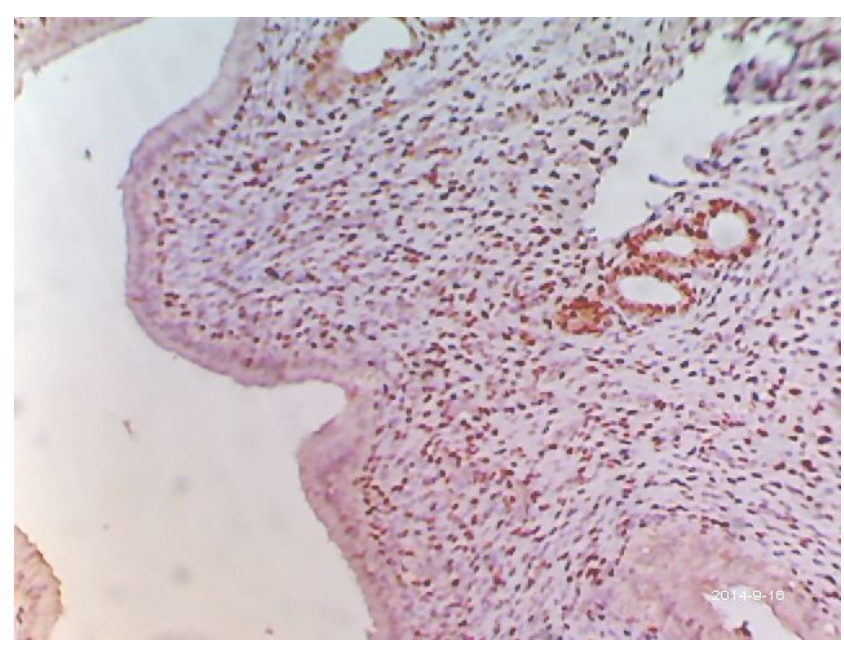

Figure 2. ER positive reaction in the glands, pseudoglands and stromal cells, and negative in luminal epithelial cells (nuclear staining), rat oviduct, follicular phase, x 150 .

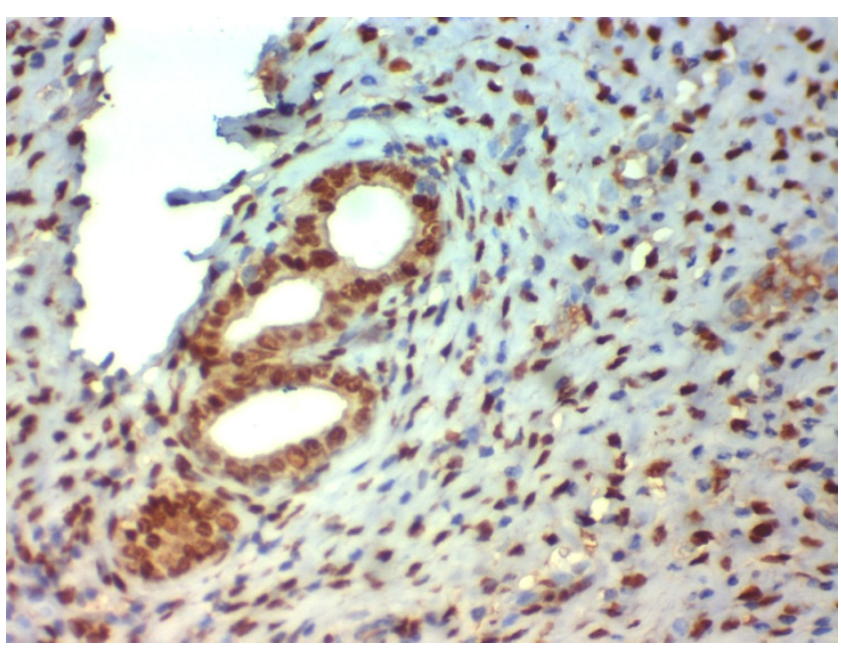

Figure 3. ER positive reaction in the glands, pseudoglands and stromal cells, rat oviduct, follicular phase, $\times 200$.

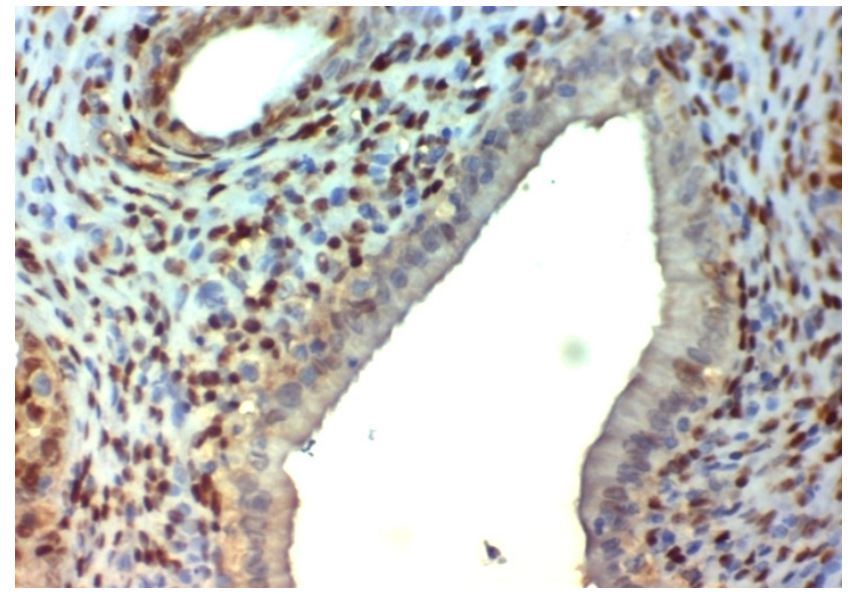

Figure 4. ER positive reaction in the glands, pseudoglands, stromal cells, and negative in the luminal epithelial cells, rat oviduct, follicular phase, $\mathrm{x}$ 200. 


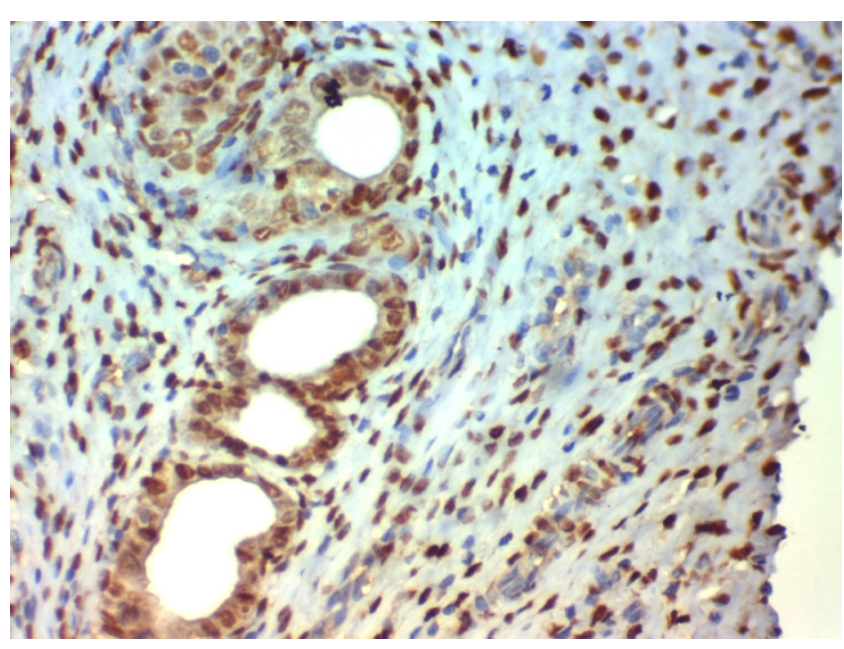

Figure 5. ER positive reaction in the glands, pseudoglands and stromal cells, rat oviduct, follicular phase, $\mathrm{x} 200$.

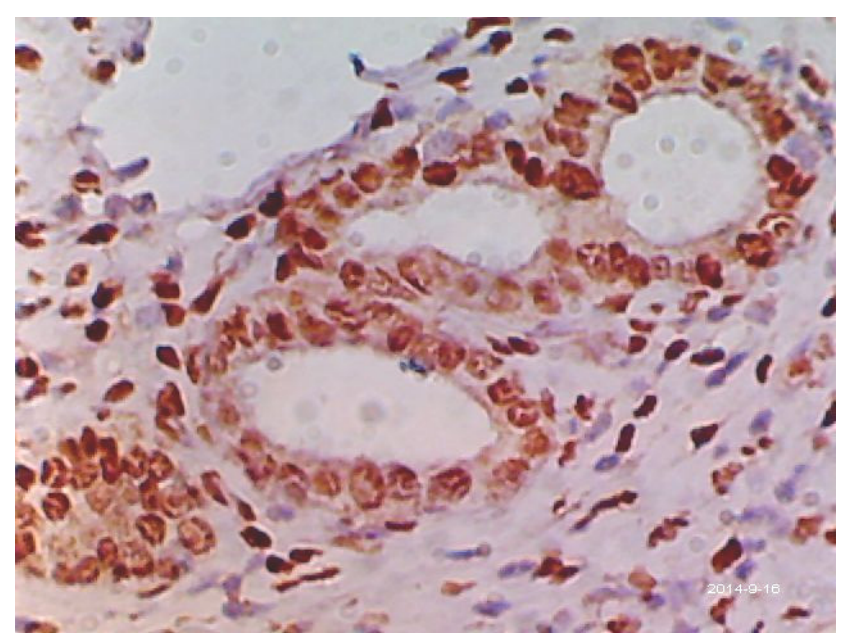

Figure 6. ER positive reaction in the glands, pseudoglands, and stromal cells (nuclear staining), rat oviduct, follicular phase, $\mathrm{x} 400$.

In the luteal stage, we noticed a strong cytoplasmic reactivity for ER in the luminal epithelial cells in four rats $(80 \%)$ associated with low reactivity in the glands, pseudoglands in one rat $(20 \%)(P=0.001)$. Low nuclear reactivity was noticed in the endothelia in one rat only (20\%), associated with absence of reactivity in the stromal or muscle cells $(P=0.001)$, (Figures 7, 8).

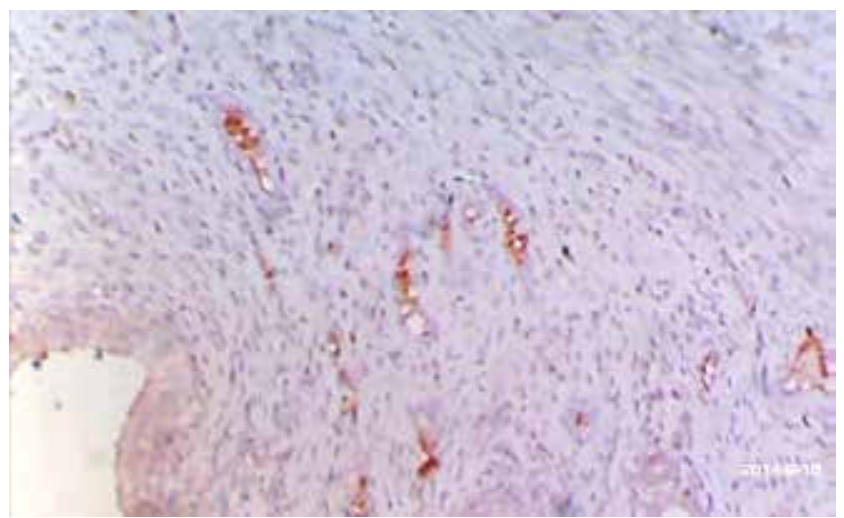

Figure 7. ER positive reaction in the endothelial cells of vascular channels, negative reaction in the stromal and luminal epithelial cells, rat oviduct, follicular phase, $\mathrm{x} 100$.

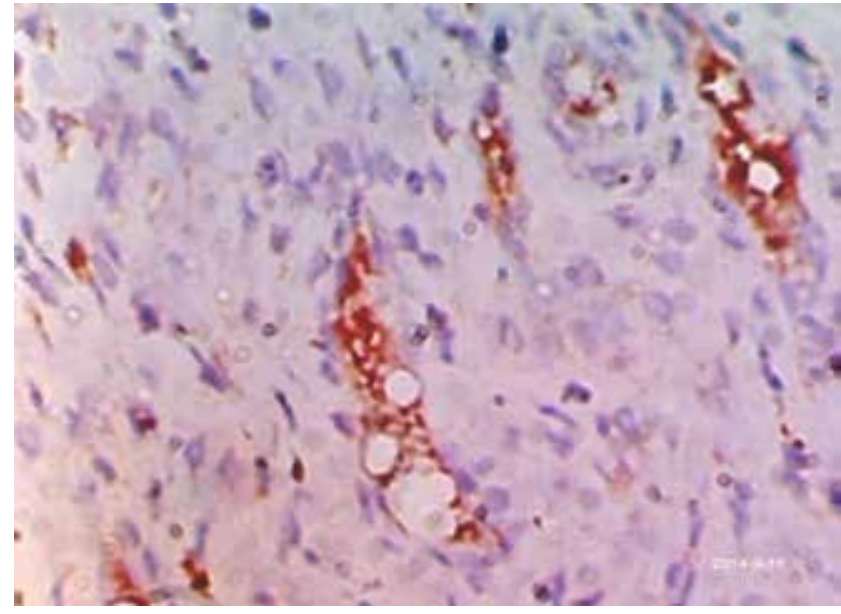

Figure 8. ER positive reaction in the endothelial cells of vascular channels (nuclear staining), negative in the stromal cells, rat oviduct, follicular phase, $\mathrm{x} 400$.

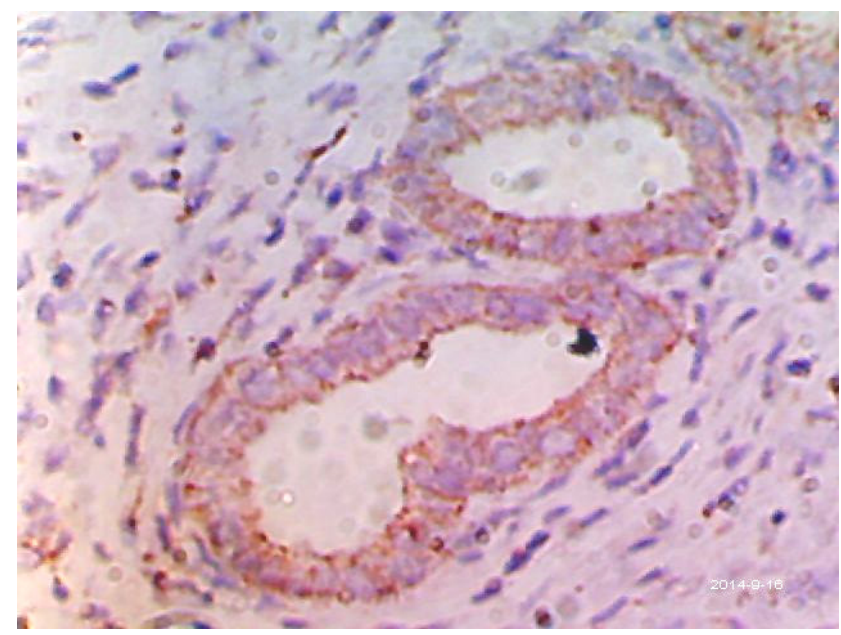

Figure 9. ER positive reaction in the glands (cytoplasmic, or membranous), rat oviduct, luteal phase, $x 400$.

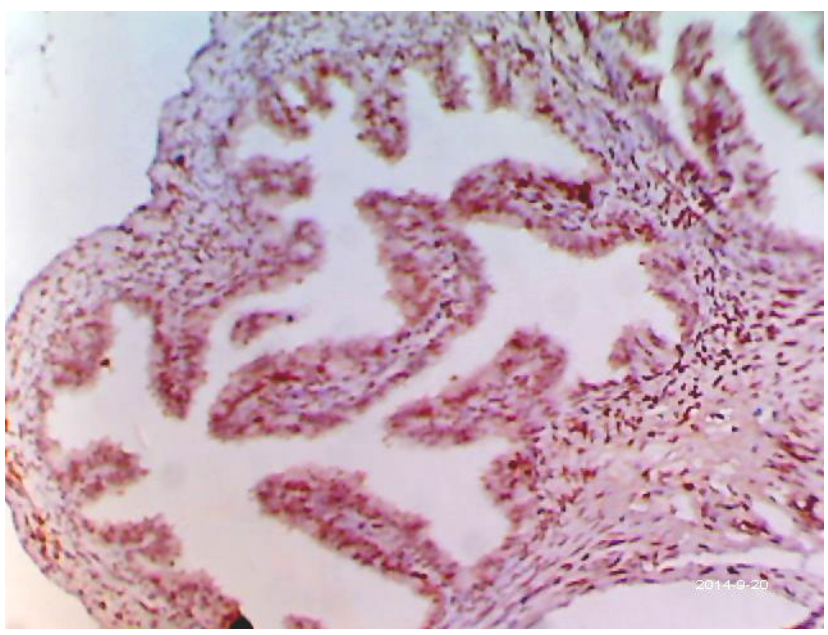

Figure 10. PR positive reaction in the luminal epithelial cells and stromal cells, rat oviduct, luteal stage, $\mathrm{x} 100$.

For PR immunoreactivity in the follicular phase, there was a strong immunoreaction in the glands, pseudoglands in 4 
rats $(80 \%)$ associated with strong reaction in luminal epithelial cells in only one rat $(20 \%)(P=0.001)$. The stromal and muscle cells were positive in all examined five rats $(100 \%)$, associated with negativity in the endothelial cells $(P$ $=0.001$ ), (Figure 9). In the luteal phase, we also found a strong nuclear reaction for PR in the luminal epithelial cells and glands or pseudoglands in three rats $(60 \%)$ (non-significant "NS" association), and in stromal and muscle cells in three rats $(60 \%)$, associated with negativity in the endothelial cells in all examined rats $(P=0.001)$, (Figure 10).

After DMPA injection, we noticed cytoplasmic immunnoreactivity of ER in luminal epithelial cells in eight rats $(80 \%)$, associated with cytoplasmic reactivity in two rats (20\%) in the glands, pseudoglands $(P=0.001)$, and reactive in the endothelial cells in two rats $(20 \%)$ associated with negativity in the stromal cells in all examined rats $(P$ $=0.001$ ).

After DMPA injection; the nuclear immunoreactivity reached the maximum for PR in the glands, pseudoglands and luminal epithelial cells in eight rats $(80 \%)$ (NS association), and reactive in stromal and muscle cells in eight rats $(80 \%)$, associated with negativity in the endothelial cells of vasculature of all ten rats $(100 \%)(P=0.001)$, (Figure 11).

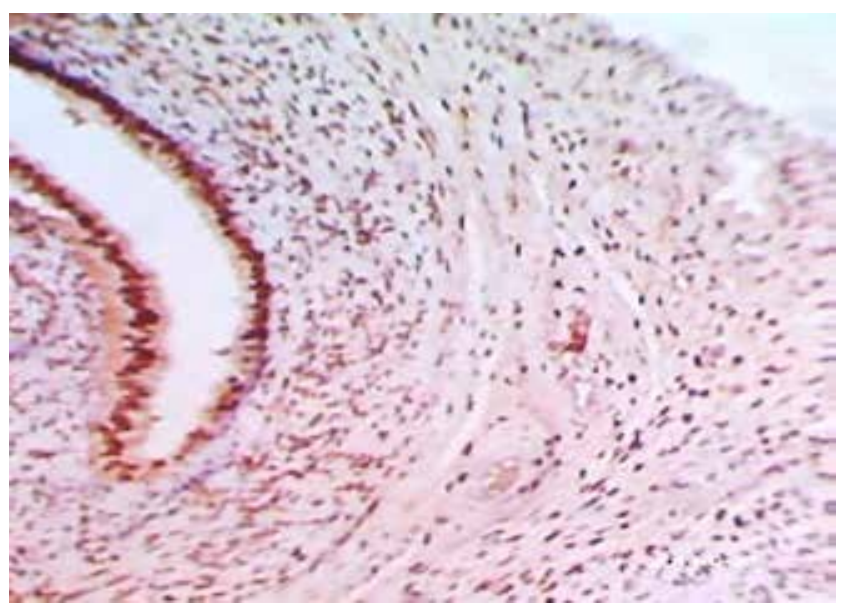

Figure 11. PR positive reaction in the luminal epithelial cells, and stromal cells (nuclear staining), rat oviduct, DMPA-treated animal, x 100.

\section{Discussion}

The estrous cycle in the rat consists of four stages known as proestrus, estrus, metestrus and diestrus [11]. During proestrus, estrogen level increases and ovarian follicles grow fast [14]. This phase lasts about $12 \mathrm{~h}$ [11]; and corresponds to follicular phase in humans. Ovulation occurs during the night of estrus 10-12 $\mathrm{h}$ after the luteinizing hormone (LH) surge. In the absence of mating at the time of ovulation, the corpora lutea are transiently functional and secrete a small amount of progesterone [15]. This phase called metestrus

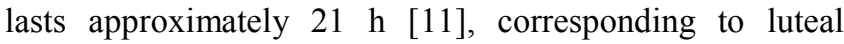
"secretory" stage.

The mammalian oviduct is not just a conducting bridge between the ovary and uterus, but it is also a sophisticated secretory organ that maintains and modulates the dynamic fluid-filled environment, necessary for fertilization and early embryonic development [16]. From the point of view of chemical composition, the tubal fluid contains ions, amino acids, proteins, growth factors, enzymes, hormones, the gamete- and embryo-protective and immunosuppressive components - taurineand hypotaurine [17] and source of energy - lactate, pyruvate and glucose [18]. The fluid originates from transudation of blood plasma and the active secretion of the epithelial cells [19]. Lauschová [20] mentioned that tubal fluid originating from blood plasma passes into the lumen via transudation from the blood vessels. However, it seems another source contributing to the tubal fluid that comes out from the glands noticed at the bottoms of crypts (Figures 1,2). The current finding is in contrary to previous results suggesting that the histoarchitecture of the Fallopian tube is simple, with a non-glandular mucosa [21]. The glands might produce a lubricating substance which facilitates the passage of the oocyte and blastocyst in the narrow isthmus [22].

The cilia of the oviduct epithelium together with muscular contractions and the follicular fluid play a major role in the transport of sperms and oocytes and are important for fertilization [23]. Different hormones have been tested for their effects on ciliary activity. Estrogen receptors (ERs) are members of the nuclear receptor superfamily and are involved in regulation of fallopian tube functions (i.e., enhancement of protein secretion, formation of tubal fluid, and regulation of gamete transport) [17]. In this study; in the follicular phase, we found increase immunoreactivity for estrogen receptors in the glands, pseudoglands, associated with negativity in the luminal epithelial cells with high significance $(P=0.001)$, this indicating proliferative activity that start in these glands, which may represent the reserve of luminal epithelial cells. We noticed also strong reactivity in the stromal cells, muscle cells that was associated with increased nuclear reactivity in the endothelial cells of vasculature $(P=0.001)$, indicating their proliferative activity, and participation in activity of the fallopian tubes. In the luteal phase, there was increase cytoplasmic reactivity of ER, in the luminal epithelial cells, associated with decrease reactivity in the glands or pseudoglands $(P=0.001)$, a sign for increased transcriptional activity, hence the secretory reactivity of the luminal epithelial cells, and decrease proliferative activity. In the same direction, we found decreased nuclear immunoreactivity of the endothelial cells associated with no reactivity in the stromal cells $(P=0.001)$. Other authors stated that estrogen receptor (ER) is immunolocalized to epithelial cells in the ampullary and fimbrial sections of the Fallopian tube and is reputed to increase throughout the follicular phase before reaching a plateau in the luteal phase [25]. Progesterone receptor (PR) in the Fallopian tube was first characterized in the early1990's [8,26]. Some studies showed that immunoexpression of epithelial PR expression was most intense in the follicular phase but it decreased along the 
luteal phase, to be undetected in the late luteal phase [25]. In our study; in the follicular phase, PR reactivity occurred in the glands, pseudoglands associated with negativity in the luminal epithelial cells $(P=0.001)$. There was marked reactivity in the stromal cells associated with negativity in the endothelial cells ( $\mathrm{p}=0.001$ ). However, in the luteal phase, the immunoreactivity becomes moderate in the luminal epithelial cells, glands, pseudoglands (NS association), stromal cells, and muscle cells but still negative in the endothelial cells $(P=0.001)$, this indicating moderate secretory activity and ciliray beats along through the luteal stage. In comparison with other animals, Tienthai et al., [27] found that: ER $\alpha$ and PR in Thai swamp buffalo oviduct vary according to the phase of ovarian activity and the regional function of the oviduct; the intensity and proportion of ER $\alpha$ and PR staining was very intense in uterine tubal junction (UTJ) and isthmus of swamp buffalo oviduct during follicular phase and less intense during luteal phase. These findings correspond to the earlier reports in heifers and cows $[28,29]$. We found association between immunoreactivity of stromal cells, muscle cells and the epithelial cells (luminal, glandular or pseudoglandular). The same result was found by Okada et al. [9] and stated that: There's interaction between epithelial and stromal cells via intermediate molecules which are produced by ER- and PRs-positive stromal cells, that control ciliogenesis regulation. After DMPA injection, we found high cytoplasmic immunoreactivity for ER in the luminal epithelial cells, associated with low reactivity in the glands, pseudoglands $(P=0.001)$ and low nuclear reactivity in the stromal cells, associated with negativity in the endothelial cells, this indicates low proliferation in the glands, stromal cells, endothelium, still some proliferative activity in the luminal epithelial cells. PR reactivity was found to be high in all epithelial cells, glands association, stromal cells, and negative in the endothelial cells $(P=0.001)$, indicating the stimulatory effect of exogenous progesterone on the PR release, thus more inhibition on the ciliary beats. Progesterone has proven to cause reduced ciliary activity and may at a high level be a cause of ectopic pregnancy [30]. Similarly, Zhao et al. [31] found that levonorgestrel, a derivative of progesterone, reduces the ciliary beat frequency without damaging ciliated cells. Ciliary dysfunction caused by endometriosis or smoking may be the reason for reduced fertility in some women [5,32]. Comparable results were obtained by Vereide et al. [33]. They stated that in patients with endometrial hyperplasia after intermittent treatment with oral medroxyprogesterone acetate for three months, there was a reduction in immunohistochemical expression of two isoforms of PR (A and $\mathrm{B}$ ) in the epithelial and stromal cells of the endometrium. From these notices, it might be concluded that DMPA can enhance PR in the fallopian tubes but reduces them in the uterine epithelial and stromal cells. In comparison to other drugs, mifepristone (progesterone antagonist) increases PR in fallopian tube while levonoprogesterone (progesterone agonist) does not change PR concentration in fallopian tubes [34].

\section{Conclusions}

In conclusion, the administration of exogenous progesterone modulates $\mathrm{PR}$, consequently affecting the function of the fallopian tube and providing a possible mechanism of contraception. Further studies are needed to understand the mechanisms by which progestins mediate stromal-epithelial interactions in female reproductive tissues. The understanding of such mechanisms is essential for the development of new contraceptive methods or the improvement of those already available [35]. Moreover, the glands or pseudoglands appearing different in immunoreactivity from the surface epithelium need more clarification in the future studies.

\section{Abbreviations}

DMPA: Depot-medroxy progesterone acetate

ER: Estrogen receptors

PR: Progesterone receptors

$\mathrm{N}$ : Nuclear expression

C: Cytoplasmic expression

NS: Non significant

\section{Conflict of Interests}

The authors declare that they have no competing interests.

\section{Authors' Contributions}

All authors contributed equally to this work. All authors read and approved the final manuscript.

\section{Acknowledgements}

We acknowledge Scientific and medical research center 'ZSMRC' of Zagazig Faculty of Medicine for its support.

\section{REFERENCES}

[1] Rodriguez-Martinez H, Tienthai P, Suzuki K, Funahashi H, Ekwall H, Johannisson A: Oviduct involvement in sperm capacitation and oocyte development. Reproduction Suppl. 2001;58:129-145.

[2] Gawronska B, Stepien A, Ziecik AJ: Effect of estradiol and progesterone on oviductal LH-receptors and LH-dependent relaxation of the porcine oviduct. Theriogenology 2000;53(3):659-672.

[3] Hunter RH: Have the Fallopian tubes a vital role promoting infertility? Acta Obstet Gynecol Scand 1998;77(5):475-486.

[4] Tazuke SI, Giudice LC: Growth factors and cytokines in 
endometrium, embryonic development, and maternal: embryonic interactions. Semin Reprod Endocrinology 1999;14(3):231-245.

[5] Lyons RA, Saridoğan E, Djahanbakhch O: The reproductive significance of human Fallopian tube cilia. Hum Reprod Update 2006;12(4):363-372.

[6] Hunter RH, Cicinelli E, Einer-Jensen N: Peritoneal fluid as an unrecognised vector between female reproductive tissues. Acta Obstet Gynecol Scand 2007;86(3):260-265.

[7] Giretti MS, Simoncini T: Rapid regulatory actions of sex steroids on cell movement through the actin cytoskeleton. Steroids 2008;73(9-10):895-900.

[8] Amso NN, Crow J, and Shaw R: Comparative immunohistochemical study of estrogen and progesterone receptors in the Fallopian tube and uterus during different stages of the menstrual cycle and the menopause. Hum. Reprod 1994; 9:1027-1037.

[9] Okada A, Ohta Y, Inoue S, Hiroi H, Muramatsu M, Iguchi T: Expression of estrogen, progesterone and androgen receptors in the oviduct of developing, cycling and pre-implantation rats. J Mol Endocrinol 2003;30:301-315.

[10] Hamid HY, Zakaria MZA: Reproductive characteristics of the female laboratory rat. African Journal of Biotechnology 2003;12(19):2510-2514.

[11] Lohmiller J, Swing SP: Reproduction and Breeding. In M. A. Suckow, S. H. Weisbroth and C. L. Franklin. The Laboratory Rat, 2nd ed., pp. 147-164, Elsevier Academic Press, 2006.

[12] Dickmann Z: Postcoital contraceptive effects of medroxyprogesterone acetate and oestrone in rats. J Reprod Fertil 1973;32:65-69.

[13] Santiago R, Arcea A, Rodriguezb AMC, Arroyob IC, Cerbonb M, Martineza MP: Progesterone receptor immunoreactivity differs in the uterus of pseudopregnant and medroxyprogesterone acetate-treated rabbits. Animal Reproduction Science 2010;120:173-178.

[14] Maeda K, Ohkura S, Tsukamura H:. Physiology of reproduction. In: Krinke GJ (Ed.). The Laboratory Rat: Handbook of Experimental Animals. London, UK: Academic Press, pp. 145-176, 2000.

[15] Johnson MH: Essential Reproduction. 6th ed. New York, NY: Wiley-Blackwell. p. 316, 2007.

[16] Kapur RP, Johnson LV: Ultrastructural evidence that specialized regions of the murine oviduct contribute a glycoprotein to the extracellular matrix of mouse oocytes. Anat Rec 1988;221:720-729.

[17] Boatman DE: Responses of gametes to the oviductal environment. Hum Reprod (Natl Suppl JBFS 2) 1997;12:133 -149 .

[18] Tay JI, Rutherford AJ, Killick SR, Maguiness SD, Partridge RJ, Leese HJ: Human tubal fluid: production, nutrient composition and response to adrenergic agents. Human Reprod 1997;11:2451-2456.

[19] Leese HJ, Tay JL, Reischl J, Downing SJ: Formation of Fallopian tube fluid: role of a neglected epithelium. Reproduction 2001;121:339-346.

[20] Lauschová I: Secretory cells and morphological manifestation of secretion in the mouse oviduct. Scripta Medica (Brno) 2003;76 (4):203-214.

[21] Brüssow KP, Rátky J, Rodriguez-Martinez H: Fertilization and Early Embryonic Development in the Porcine Fallopian Tube. Reprod Dom Anim 2008;43 (Suppl. 2):245-251.

[22] Chatkoff ML: A biophysical model of the mechanisms regulating ovum transport in rates. In: Ovum transport and fertility regulation (WHO symposium, San Antonio, Texas, 1975). Harper M J K, Pauerstein C J (eds), Copenhagen, pp.27-40, 1975.

[23] Mahmood T, Saridogan E, Smutna S, Habib AM, Djahanbakeh O: The effect of ovarian steroids on epithelial ciliary beat frequency in the human Fallopian tube. Human Reproduction 1998;13(11):2991-2994.

[24] Shao R, Egecioglu E, Weijdegård B, Kopchick JJ, Fernandez-Rodriguez J, Andersson N, Billig H: Dynamic regulation of estrogen receptor- isoform expression in the mouse fallopian tube: mechanistic insight into estrogen-dependent production and secretion of insulin-like growth factors. Am J Physiol Endocrinol Metab 2007;293:E1430-E1442.

[25] Mangelsdorf DJ, Thummel C, Beato M, Herrlich P, Schütz G, Umesono K, Blumberg B, Kastner P, Mark M, Chambon P, Evans RM: The nuclear receptor superfamily: the second decade. Cell 1995;83(6):835-839.

[26] Coppens MT, de Boever JG, Dhont MA, Serreyn RF, Vandekerckhove DA, Roels HJ: Topographical distribution of oestrogen and progesterone receptors in the human endometrium and Fallopian tube. An immunohistochemical study. Histochemistry 1994;99(2):127-131.

[27] Tienthai $\mathrm{P}$, Sajjarengpong $\mathrm{K}$, Techakumphu M: Immunohistochemical Study of Estrogen and Progesterone Receptor in Thai Swamp Buffalo Oviductal Epithelium at Follicular and Luteal. Proceedings, The 15th Congress of FAVA 2008,257-260, Accessible at: http://www.vet.chula.ac.th/vet2014/Ebook/ebook/FAVA200 8/paperfile/PC049.pdf

[28] Båge R, Masironi B, Sahlin L, Rodríguez-Martínez H: Deviant peri-oestrual hormone patterns affect the epithelium of the uterine tube in repeat-breeder heifers. Reprod. Fertil. Dev. 2002;14:461-469.

[29] Valle GR1, Cassali GD, Nogueira JC, Castro AC, Reis AM, Cardoso FM, Figueiredo CB, Nascimento EF: Nuclear estrogen and progesterone receptors in the oviduct of heifers under natural and superovulated estrous cycles. Anim. Reprod. Sci. 2007;101:28-37.

[30] Paltieli Y, Eibschitz I, Ziskind G, Ohel G, Silbermann M, Weichselbaum A: "High Progesterone Levels and Ciliary Dysfunction- A Possible Cause of Ectopic Pregnancy" Journ. of Ass. Repr. and Gentics 1999;17 (2):104-106.

[31] Zhao W, Zhu Q, Yan M, Li C, Yuan J, Qin G, Zhang J. Levonorgestrel decreased cilia beat frequency of human fallopian tubes and rat oviducts without changing the morphological structure. Clin Exp Pharmacol Physiol. 2014; 15. Accessible at: http://www.ncbi.nlm.nih.gov/pubmed/?ter $\mathrm{m}=$ Levonorgestrel + decreased + cilia + beat + frequency + of + hu man+fallopian+tubes

[32] Nutu M: "The role of progesterone in the regulation of ciliary activity in the fallopian tube" University of Gothenburg, 2009. 
40 DMPA- Induced Changes in Estrogen and Progesterone Receptors of Ampulla of Rat- oviducts: An Immunohistochemical Study

Accessible at: ttps://gupea.ub.gu.se/bitstream/2077/21415/4/ gupea_2077_21415_4.pdf

[33] Vereide AB, Kaino T, Sager G, Arnes M, Ørbo A: Effect of levonorgestrel IUD and oral medroxyprogesterone acetate on glandular and stromal progesterone receptors (PRA and PRB), and estrogen receptors (ER-alpha and ER-beta) in human endometrial hyperplasia. Gynecol. Oncol 2006;101(2):214223.
[34] Christow A, Sun X, Gemzell-Danielsson K: Effect of mifepristone and levonorgestrel on expression of steroid receptors in the human Fallopian tube. Mol Hum Reprod 2002;8(4):333-340.

[35] Rivera R, Yacobson I, Grimes D: The mechanism of action of hormonal contraceptives and intrauterine contraceptive devices. Am J Obstet Gynecol 1999;181:1263-1269 